\title{
Hubungan Motivasi Kerja dan Disiplin Kerja dengan Kinerja Pegawai di Dinas Pendidikan Kabupaten Mojokerto
}

\author{
Sigit Priyo Sembodo \\ ${ }^{1}$ Pascasarjana Institut Pesantren Kh. Abdul Chalim Pacet Mojokerto \\ e-mail: sigit.ikhac@gmail.com
}

Submitted: 01-01-2020 Revised : 15-02-2020 Accepted: 03-03-2020

\begin{abstract}
An organization of good governance should have the motivation of employees with high job of work and discipline. If employees work well in accordance with the ability and motivation work influenced by their skills and responsible for his job as a form of discipline work and an organization that will be able to more developed ease the achievement of the purpose of the organization. The purpose of this study are (1) the correlation between work motivation with employee performance, (2) the correlation between work discipline with employee performance, (3) the correlation between work motivation and work discipline with the performance of employees in educational department of mojokerto.A method in this research was used a quantitative approach. The techniques to take data collection here is closed questionnaires and Data processing techniques uses correlation product moment test and multiple correlation with the significant level of 5\% to know is there any relationship between the variables or not.

The result showed that (1) it is proved that there is correlation between work motivation and performance of employees with a correlation coefficient of 0.792 , (2) there is a correlation between the work discipline with employee performance with a correlation coefficient of 0.981 , (3) there is a correlation between work motivation and work discipline with the employee's performance with a correlation coefficient of 0.981 . Based on the analysis of the data above it can be concluded that there are correlation between work motivation and work discipline with the employees performance in educational department of mojokerto.
\end{abstract}

Keywords: work motivation, work discipline, employees performance

doi) https:

How to Cite
Sigit Priyo Sembodo. (2020). Hubungan Motivasi Kerja dan Disiplin Kerja dengan Kinerja Pegawai di Dinas Pendidikan Kabupaten Mojokerto. Munaddhomah: Jurnal Manajemen Pendidikan Islam, Volume 1 (1), 65-74.

\section{PENDAHULUAN}

Di era perkembangan zaman seperti saat ini, manusia merupakan salah satu sumber daya yang sangat penting dalam sebuah organisasi. Tidak hanya sebagai seorang pekerja dan hanya digaji dalam suatu organisasi, tetapi merupakan unsur utama dalam mempertahankan kelangsungan hidup dan pertumbuhan organisasi di masa yang akan datang (Arifudin et al., 2017; Megawangi, 2005; Ubabuddin, 2019). Pada dasarnya organisasi bukan saja mengharapkan SDM yang mampu, cakap dan terampil, tetapi yang terpenting mereka mau bekerja dengan keras dan bertanggung jawab terhadap tugas-tugas yang diberikan kepadanya. Apabila seseorang bekerja secara profesional sesuai dengan kemampuan dan keahliannya yang dipengaruhi oleh motivasi mereka dan bekerja sesuai dengan norma-norma atau ketentuan organisasi dan bertanggung jawab terhadap tugasnya sebagai bentuk disiplin kerja, maka suatu organisasi akan dapat berkembang dan dapat mencapai tujuannya(E Mulyasa, 2011; Hamzah B, 2011; Wendt \& Gone, 2016). 
Sebagai aparatur pemerintahan, Pegawai Negeri Sipil bertugas memberikan pelayanan kepada masyarakat secara profesional, jujur dan adil serta kesungguhan dalam menjalankan tugas dan kesanggupan berkorban, dalam arti mengorbankan kepentingan pribadi dan golongan untuk kepentingan negara dan masyarakat yang dilandasi kesetiaan dan ketaatan kepada Pancasila dan Undang-undang Dasar 1945. Penyelenggaraan pemerintahan memerlukan orang-orang yang mampu untuk melaksanakan tugas dan tanggung jawabnya untuk berpartisipasi dalam pemerintah, pembangunan dan kemasyarakatan. Undang-undang No. 8 Tahun 1974 tentang Pokok-Pokok Kepegawaiaan sebagaimana telah diubah dengan Undang-undang No. 43 Tahun 1999 yang menyatakan bahwa kelancaran penyelenggaraan tugas pemerintah dan pembangunan nasional sangat bergantung pada kesempurnaan aparatur negara khususnya Pegawai Negeri.

Dalam sebuah organisasi perlu kiranya memperhatikan kinerja para pegawai disetiap pekerjaannya. Hal itu dikarenakan apabila kinerja pegawai mengalami penurunan maka akan dapat berpengaruh terhadap hasil kerja yang akan dicapai kurang maksimal. (Swasto, 2011, p. 54) mengemukakan bahwa "kinerja atau prestasi kerja adalah hasil atau prestasi yang telah dicapai oleh seseorang dalam melaksanakan pekerjaannya sesuai dengan standar dan kriteria yang ditetapkan oleh pekerjaan itu". Kinerja juga diartikan sebagai hasil keterkaitan antara usaha, kemampuan, dan persepsi tugas. Kinerja juga disebut dengan performasi atau prestasi kerja. Menurut (Mangkunegara, 2000, p. 67) menyatakan bahwa "kinerja karyawan (prestasi kerja) adalah hasil kerja secara kualitas dan kuantitas yang dicapai oleh seseorang karyawan dalam melaksanakan tugasnya sesuai dengan tangung jawab yang diberikan kepadanya”. Kualitas kerja merupakan mutu hasil kerja yang didasarkan pada standar yang telah ditetapkan(Abdullah, 2014; Ekosusilo \& Soepardjo, 2014). Kualitas kerja dapat diukur melalui ketepatan, ketelitian, ketrampilan dan kebersihan hasil kerja sedangkan kuantitas kerja ditunjukkan melalui hasil dan kecepatan dalam melaksanakan pekerjaan. Kinerja pegawai yang optimal akan memungkinkan organisasi untuk memberikan pelayanan kepada masyarakat secara profesional, jujur dan adil (Aprilianto \& Arif, 2019; Kartiko \& Azzukhrufi, 2019). Para pegawai akan bekerja dengan kesungguhan dalam menjalankan tugas dan kesanggupan berkorban, dalam arti mengorbankan kepentingan pribadi dan golongan untuk kepentingan negara dan masyarakat sesuai dengan Pancasila dan Undangundang Dasar 1945.

Motivasi perlu dimiliki oleh seorang pegawai dalam bekerja karena dengan motivasi yang ada pada dirinya maka, pegawai akan terdorong untuk melakukan suatu sikap untuk mencapai kepuasan dirinya. Robbins dalam (Wahjono, 2010, p. 78, 2015) menyatakan bahwa motivasi adalah "kesediaan untuk mengeluarkan tingkat upaya yang tinggi untuk tujuan organisasi yang dikondisikan oleh kemampuan upaya itu dalam memenuhi beberapa kebutuhan individual". Motivasi merupakan serangkaian sikap dan nilai-nilai yang mempengaruhi seorang individu untuk mencapai hal yang spesifik sesuai dengan tujuan individu (Ma arif \& Rochmah, 2018; Suprihatin, 2015).

Hal tersebut yang menguatkan peneliti untuk melakukan penelitian di Dinas Pendidikan Kabupaten Mojokerto yakni khususnya mengenai motivasi kerja dan disiplin kerja seperti apa yang diterapkan di Dinas Pendidikan Kabupaten Mojokerto sehingga kedepannya dapat memberikan pelayanan yang prima kepada seluruh masyarakat dan dapat meningkatkan kualitas pendidikan di Kabupaten Mojokerto. Hal tersebut tidaklah mungkin dapat tercapai tanpa dukungan kinerja pegawai yang profesional. Selain alasan tersebut, penelitian mengenai motivasi kerja, disiplin kerja dan kinerja pegawai di Dinas Pendidikan Kabupaten Mojokerto belum pernah ada yang meneliti sebelumnya.

Berdasarkan hasil studi pendahuluan yang dilakukan oleh peneliti di tempat penelitian, indikasi rendahnya kinerja di Dinas Pendidikan Kabupaten Mojokerto dapat dilihat dari masih adanya pegawai yang terlambat dalam menyelesaikan tugas dan mengurus suatu berkas. Disaat jam kerja masih juga ada beberapa pegawai yang tidak berada di kantor. Hal itu akan dapat berpengaruh, sehingga kinerja yang dicapai oleh pegawai tidak sesuai dengan tujuan yang telah 
ditetapkan. terbukti dengan data hasil pengukuran kinerja kegiatan (PKK) pada tahun 2013 oleh Dinas Pendidikan Kabupaten Mojokerto yang menunjukkan presentase pencapaian kinerja secara keseluruhan masih kurang dari 60\%. Kurangnya efektivitas pelayanan yang diberikan pegawai dapat dipengaruhi oleh kurangnya motivasi mereka, sehingga para pegawai cenderung mengalami penurunan kinerja. Kemudian masih rendahnya tingkat kedisiplinan pegawai juga masih terlihat, hal itu dapat dibuktikan dengan seringnya beberapa pegawai yang datang tidak tepat waktu ke kantor sehingga tidak bisa mengikuti kegiatan apel pagi yang menjadi rutinitas seluruh warga Dinas Pendidikan Kabupaten Mojokerto setiap harinya sebelum memulai aktifitas kerja. Para pegawai terlihat kurang bersemangat dalam bekerja, dapat dibuktikan dari mereka tidak mampu menyelesaikan tugas dengan tepat sesuai dengan waktu yang telah ditargetkan. Dengan pemikiran tersebut, maka peneliti ingin melakukan penelitian lebih lanjut mengenai kinerja pegawai yang masih belum memenuhi standar kinerja kegiatan dari Dinas Pendidikan Kabupaten Mojokerto tersebut berhubungan dengan variabel motivasi kerja pegawai dan disiplin kerja pegawai. Dengan memperhatikan keadaan dan permasalahan yang ada pada organisasi tersebut maka penelitian ini diberi judul "Hubungan Motivasi Kerja dan Disiplin Kerja dengan Kinerja Pegawai di Dinas Pendidikan Kabupaten Mojokerto". Rumusan Masalah yang akan diangkat dalam penelitian ini adalah: 1) Adakah hubungan antara motivasi kerja dengan kinerja pegawai di Dinas Pendidikan Kabupaten Mojokerto ? 2) Adakah hubungan antara disiplin kerja dengan kinerja pegawai di Dinas Pendidikan Kabupaten Mojokerto ? 3) Adakah hubungan antara motivasi kerja dan disiplin kerja dengan kinerja pegawai di Dinas Pendidikan Kabupaten Mojokerto?

\section{KAJIAN TEORI}

Menurut Nimran (1999:45) berpendapat bahwa "motivasi yakni usaha, menunjukkan kepada kekuatan perilaku kerja seseorang atau jumlah yang ditunjukkan oleh seseorang dalam pekerjaannya". Menurut Wahosumidjo dalam (Hamzah B, 2011) mengemukakan bahwa "motivasi merupakan dorongan dan kekuatan dalam diri seseorang untuk melakukan tujuan tertentu yang ingin dicapainya". Tujuan disini diartikan sesuatu yang berada di luar diri manusia sehingga kegiatan manusia lebih terarah karena seseorang akan berusaha lebih semangat dan giat dalam berbuat sesuatu. Menurut (Siagian, 2002, p. 138) motivasi adalah:

Daya pendorong yang mengakibatkan seseorang anggota organisasi mau dan rela untuk mengerahkan kemampuan dalam bentuk keahlian atau ketrampilan, tenaga dan waktunya untuk menyelenggarakan berbagai kegiatan yang menjadi tanggung jawabnya dan menunaikan kewajibannya, dalam rangka pencapaian tujuan dan berbagai sasaran organisasi yang telah ditentukan sebelumnya.

Maka dari itulah sebuah motivasi kerja sangat perlu diberikan kepada para bawahan dan pengikutnya dalam sebuah organisasi, sebagaimana dikemukakan Arifin, dkk (2003:57) bahwa "motivasi karyawan dalam suatu perusahaan sangatlah penting karena berpengaruh terhadap pencapaain tingkat produktivitas".

Menurut (Stoner et al., 1996, p. 90) mendiskripsikan tahapan atau proses membentuk disiplin yaitu, "disiplin biasanya diambil secara bertahap seperti peringatan, teguran, percobaan, penundaan, transfer disiplin, demosi dan PHK sampai masalah itu terpecahakan atau dihilangkan". Subardhy dalam Maghfur (2005:39) mengatakan bahwa "disiplin adalah sikap mental yang tercermin dalam perilaku atau perbuatan perorangan, kelompok atau masyarakat berupa kebutuhan atau ketaatan terhadap peraturan-peraturan yang ditetapkan oleh pemerintah, atasan atau etik, norma dan kaidah yang berlaku dalam masyarakat untuk tujuan tertentu". Menurut Sulistriyani dalam (Barmawi, 2017).

Disiplin pada dasarnya merupakan tindakan manajemen untuk mendorong agar para anggota organisasi dapat memenuhi berbagai ketentuan dan peraturan yang berlaku dalam suatu 
organisasi, yang mencakup (1) adanya tata tertib atau ketentuan-ketentuan; (2) adanya kepatuhan para pengikut; dan (3) adanya sanksi bagi pelanggar.

Dari beberapa pendapat diatas disimpulkan bahwa disiplin merupakan sikap seseorang yang dengan kesadaran dan kesediaan dirinya untuk patuh terhadap segala peraturan yang berlaku dalam sebuah organisasi.

Dalam Kamus Besar Bahasa Indonesia (Badudu \& Zain, 1994)"kinerja adalah suatu yang dicapai atau prestasi yang diperlihatkan, atau kemampuan kerja". Kinerja itu sendiri dapat dilihat dari prestasi kerja atau hasil kerja yang dicapai oleh seseorang dalam melaksanakan tugasnya masing-masing. Menurut Moeheriono (2010:60) "kinerja atau performance merupakan gambaran mengenai tingkat pencapaian pelaksanaan suatu progam kegiatan atau kebijakan dalam mewujudkan sasaran, tujuan, visi dan misi organisasi yang dituangkan melalui perencanaan strategis suatu organisasi".

Kinerja merupakan hasil usaha yang dicapai seseorang sesuai dengan kemampuan dan prestasi yang ia miliki. Dalam sebuah organisasi, kinerja dapat diartikan sebagai suatu gambaran mengenai keadaan pencapaian pelaksanaan progam atau kebijakan yang telah dibuat sesuai dengan perencanaan yang telah ditentukan sebelumnya. Menurut Moeheriono (2010:60) pengukuran kinerja (performance measurement) mempunyai pengertian "suatu proses penilaian tentang kemajuan pekerjaan terhadap tujuan dan sasaran dalam pengelolaan sumber daya manusia untuk menghasilkan barang dan jasa, termasuk informasi atas efesiensi serta efektifitas tindakan dalam mencapai tujuan organisasi”. Pengukuran kinerja pegawai sangatlah perlu dilakukan, sebab dengan pengukuran kinerja ini akan dapat diketahui seberapa jauh kemampuan pegawai dalam melaksanakan tugas dan pekerjaanya yang telah dibebankan kepadanya.

Mangkunegara (2007:13) Kinerja individu adalah "hasil kerja karyawan baik dari segi kualitas maupun kuantitas berdasarkan standar kerja yang telah ditentukan". Kinerja individu akan tercapai apabila didukung oleh atribut individu, upaya kerja (work effort) dan dukungan organisasi. Sedangkan menurut (Sinambela, 2016, p. 5) "Kinerja pegawai didefinisikan sebagai kemampuan pegawai dalam melakukan sesuatu keahlian tertentu"

\section{HASIL DAN PEMBAHASAN}

Berdasarkan hasil jawaban responden, maka dapat diketahui bahwa nilai rata-rata variabel motivasi kerja sebesar 83,10. kemudian nilai minimal variabel motivasi kerja sebesar 65 dan nilai maksimal sebesar 95. Diketahui bahwa responden yang menjawab skor sangat tidak setuju (STS) sebesar $0,12 \%$, responden yang menjawab tidak setuju (TS) sebesar 13,32\% kemudian responden yang menjawab setuju (S) sebesar 40,74\% dan responden yang menjawab sangat setuju (SS) sebesar 45,81\%. Hal ini menunjukkan bahwa responden memiliki motivasi kerja yang tinggi, terlihat dari jawaban responden yang cenderung menjawab setuju dan sangat setuju. Jadi dapat disimpulkan bahwa motivasi kerja di Dinas Pendidikan Kabupaten Mojokerto sangat tinggi.

Berdasarkan hasil jawaban responden, maka dapat diketahui bahwa nilai rata-rata variabel disiplin kerja sebesar 78,99. kemudian nilai minimal variabel disiplin kerja sebesar 62 dan nilai maksimal sebesar 92. Diketahui bahwa responden yang menjawab skor sangat tidak setuju (STS) sebesar $0,04 \%$, responden yang menjawab tidak setuju (TS) sebesar 13,83\% kemudian responden yang menjawab setuju (S) sebesar 43,08\% dan responden yang menjawab sangat setuju (SS) sebesar 43,04\%. Hal ini menunjukkan bahwa responden memiliki disiplin kerja yang tinggi, terlihat dari jawaban responden yang cenderung menjawab setuju dan sangat setuju. Jadi dapat disimpulkan bahwa disiplin kerja di Dinas Pendidikan Kabupaten Mojokerto sangat tinggi.

Berdasarkan hasil jawaban responden, maka dapat diketahui bahwa nilai rata-rata variabel kinerja pegawai sebesar 81,40. Kemudian nilai minimal variabel kinerja pegawai sebesar 64 dan nilai maksimal sebesar 96. Diketahui bahwa responden yang menjawab skor sangat tidak setuju 
(STS) sebesar 0,45\%, responden yang menjawab tidak setuju (TS) sebesar 14,39\% kemudian responden yang menjawab setuju (S) sebesar 44,25\% dan responden yang menjawab sangat setuju (SS) sebesar 40,91\%. Hal ini menunjukkan bahwa responden memiliki kinerja yang tinggi, terlihat dari jawaban responden yang cenderung menjawab setuju dan sangat setuju. Jadi dapat disimpulkan bahwa kinerja di Dinas Pendidikan Kabupaten Mojokerto sangat tinggi.

Uji persyaratan analisis penelitian ini sebagai berikut:

\section{Uji Normalitas}

Uji normalitas dalam penelitian ini menggunakan Kolmogrov-Smirnov. Kriteria pengujian apabila nilai asymp.sig ( 2 tailed) $>0,05$. Berdasarkan tabel uji Kolmogorov-Smirnov dapat dilihat bahwa nilai asymp.sig untuk variabel motivasi kerja (X1) adalah sebesar 0,200 $\geq 0,05$ maka dapat dikatakan data variabel tersebut berdistribusi normal. Kemudian untuk variabel disiplin kerja (X2) nilai asymp.sig ( 2 tailed) adalah sebesar $0,115 \geq 0,05$ maka dapat dikatakan data variabel tersebut berdistribusi normal. Dan untuk variabel kinerja pegawai $(\mathrm{Y})$ nilai asymp.sig (2 tailed) adalah sebesar $0,071 \geq 0,05$ maka dapat dikatakan data variabel tersebut berdistribusi normal.

\section{Uji Linieritas}

Berdasarkan dari hasil pengujian linieritas hubungan antara X1 terhadap Y dengan menggunakan teknik One Way Anova dapat diketahui bahwa menunjukkan taraf signifikasi dengan nilai sig $=0,458$ berarti $\mathrm{p}>0,05$. Hal ini menunjukkan bahwa variabel motivasi kerja dalam penelitian ini berhubungan secara linier dengan kinerja pegawai. Selanjutnya berdasarkan hasil pengujian linieritas hubungan antara X2 terhadap Y dengan menggunakan teknik One Way Anova dapat diketahui bahwa menunjukkan taraf signifikasi dengan nilai sig $=0,187$ berarti $\mathrm{p}>$ 0,05. Hal ini menunjukkan bahwa variabel disiplin kerja dalam penelitian ini berhubungan secara linier dengan kinerja pegawai.

\section{Uji Homogenitas}

Uji homogenitas dalam penelitian ini dengan menggunakan Levene's Tes, digunakan untuk mengetahui apakah data yang akan dianalisis memiliki kesamaan varian antar kelompok. Apabila taraf signifikan dari nilai Levene Fhitung menunjukkan taraf signifikasi lebih dari $>0,05$ maka dapat dikatakan tidak ada perbedaan varian antar kelompok sampel atau dengan kata lain varian antar kelompok adalah sama. Berdasarkan hasil uji homogenitas antara X1 dengan Y menunjukkan bahwa taraf signifikan antar kelompok atau nilai Fhitung adalah 0,068 yang berarti bahwa Fhitung $>0,05$. Hal ini menjelaskan bahwa tidak ada perbedaan varian antar kelompok sampel atau dapat dikatakan varian antar kelompok adalah sama. Selanjutnya Berdasarkan hasil uji homogenitas antara X2 dengan Y menunjukkan bahwa taraf signifikan antar kelompok atau nilai Fhitung adalah 0,082 yang berarti bahwa Fhitung $>0,05$. Hal ini menjelaskan bahwa tidak ada perbedaan varian antar kelompok sampel atau dapat dikatakan varian antar kelompok adalah sama.

\section{Uji Hipotesis}

Untuk mengetahui Hubungan Motivasi Kerja (X1) dengan Kinerja Pegawai (Y) yakni dengan menggunakan korelasi product moment. Pada tabel akan diketahui besarnya Hubungan motivasi kerja (X1) dengan kinerja pegawai (Y) dan penerimaan hipotesis yang telah diajukan. Deskripsi dari nilai Pearson Correlation motivasi kerja dengan kinerja pegawai yakni sebesar 0,792. Hal ini menunjukkan terdapat hubungan yang kuat antara variabel motivasi kerja (X1) dengan kinerja pegawai $(\mathrm{Y})$ dan diketahui nilai signifikan yang diperoleh adalah 0,000 . Nilai signifikan ini lebih kecil dari pada nilai alpha 0,05 dengan demikian H01 ditolak dan Ha1 diterima. Artinya Motivasi Kerja (X1) berhubungan dengan Kinerja Pegawai (Y).

Untuk mengetahui Hubungan Disiplin Kerja (X2) dengan Kinerja Pegawai (Y) yakni dengan menggunakan korelasi product moment. Pada tabel akan diketahui besarnya Hubungan disiplin kerja (X2) dengan kinerja pegawai (Y) dan penerimaan hipotesis yang telah diajukan. 
Deskripsi dari nilai Pearson Correlation disiplin kerja dengan kinerja pegawai yakni sebesar 0,981. Hal ini menunjukkan terdapat hubungan yang sangat kuat antara variabel disiplin kerja (X2) dengan kinerja pegawai $(\mathrm{Y})$ dan diketahui nilai signifikan yang diperoleh adalah 0,000 . Nilai signifikan ini lebih kecil dari pada nilai alpha 0,05 dengan demikian H02 ditolak dan Ha2 diterima. Artinya Disiplin Kerja (X1) berhubungan dengan Kinerja Pegawai (Y).

Untuk mengetahui Hubungan Motivasi Kerja (X1) dan Disiplin Kerja (X2) dengan Kinerja Pegawai (Y) yakni dengan menggunakan korelasi ganda. Deskripsi dari tabel korelasi ganda nilai $\mathrm{R}$ yakni sebesar 0,981 . Hal ini menunjukkan terdapat hubungan yang kuat antara variabel motivasi kerja (X1) dan disiplin kerja (X2) dengan kinerja pegawai (Y) dan diketahui nilai signifikan yang diperoleh adalah 0,000. Nilai signifikan ini lebih kecil dari pada nilai alpha 0,05 dengan demikian H03 ditolak dan Ha3 diterima. Artinya Motivasi Kerja (X1) dan Displin Kerja (X2) berhubungan dengan Kinerja Pegawai (Y).

Berdasarkan hasil analisis penelitian ini dapat disimpulkan bahwa motivasi kerja (X1) berhubungan dengan kinerja pegawai $(\mathrm{Y})$ di Dinas Pendidikan Kabupaten Mojokerto. Hipotesis pertama terjawab dengan melihat nilai signifikan yang diperoleh adalah 0,000 . Nilai signifikan ini lebih kecil dari pada nilai alpha 0,05 maka dapat disimpulkan bahwa motivasi kerja berhubungan dengan kinerja pegawai sehingga hipotesis pertama teruji kebenarannya.

Uno (Hamzah B, 2011, p. 71) mengemukakan bahwa motivasi merupakan salah satu faktor yang turut menentukan kinerja seseorang. Besar atau kecilnya pengaruh motivasi pada seseorang tergantung pada seberapa banyak intensitas motivasi yang diberikan. Dengan motivasi kerja yang tinggi maka pegawai akan lebih meningkatkan prestasi kerja yang erat kaitannya dengan kinerja mereka sendiri. Hasil penelitian Mc Clelland (1961), (Gordon et al., 2019) Edward Murray (1957), dan Gordon W (1970) dalam (Mangkunegara, 2005:76) mengemukakan bahwa pimpinan, manajer, dan pegawai yang mempunyai motivasi berprestasi lebih tinggi akan mencapai kinerja yang tinggi, sebaliknya jika kinerjanya rendah maka motivasi yang dimiliki juga rendah. Motivasi kerja yang tinggi akan berdampak pula pada kinerja yang tinggi. Tidak hanya berlaku pada pimpinan organisasi saja, manajer bahkan para pegawainya akan memiliki kinerja yang tinggi apabila dalam dirinya terdapat motivasi yang tinggi begitupun sebaliknya. Artinya ada hubungan yang positif antara motivasi kerja dengan kinerja.

Berdasarkan hasil analisis data dan beberapa pendapat para ahli mengenai keterkaitan antara Motivasi Kerja dengan Kinerja Pegawai di Dinas Pendidikan Kabupaten Mojokerto, maka dapat disimpulkan bahwa terdapat hubungan yang nyata antara Motivasi Kerja dengan Kinerja Pegawai. Sehingga dapat disimpulkan bahwa hasil penelitian ini mendukung teori yang telah ada.

Berdasarkan hasil analisis penelitian ini dapat disimpulkan bahwa disiplin kerja (X2) berhubungan dengan kinerja pegawai $(\mathrm{Y})$ di Dinas Pendidikan Kabupaten Mojokerto. Hipotesis kedua terjawab dengan melihat nilai signifikan yang diperoleh adalah 0,000 . Nilai signifikan ini lebih kecil dari pada nilai alpha 0,05 maka dapat disimpulkan bahwa disiplin kerja berhubungan dengan kinerja pegawai sehingga hipotesis kedua teruji kebenarannya.

Disiplin kerja merupakan suatu bentuk pelatihan untuk menumbuhkan kesadaran dan kesediaan bagi para pegawai untuk dapat mentaati semua peraturan dan norma yang berlaku dalam organisasi. Besarnya rasa tanggung jawab seorang pegawai akan tugas dan pekerjaanya merupakan cerminan bahwa pegawai tersebut memiliki disiplin kerja yang tinggi. Seorang pegawai yang disiplin dalam bekerja dia akan selalu menggunakan waktu kerja secara efektif sesuai dengan norma yang berlaku dalam organisasi, berusaha tidak melakukan pelanggaran peraturan-peraturan yang telah ditetapkan oleh atasan dan selalu bertanggungjawab terhadap tugas dan pekerjaan. Hal ini sesuai dengan pendapat Sastrohadiwiryo (2005:291) yang menyatakan bahwa "disiplin kerja adalah suatu sikap menghormati, menghargai, patuh dan taat terhadap peraturan-peraturan yang berlaku, baik yang tertulis maupun tidak tertulis serta sanggup menjalankannya dan tidak mengelak untuk menerima sanksi-sanksinya apabila melanggar tugas dan wewenang yang diberikan kepadanya". 
Selanjutnya mengenai prestasi kerja menurut (Hasibuan, 1988, p. 75) adalah " suatu hasil kerja yang dicapai seseorang dalam melaksanakan tugas-tugas yang dibebankan kepadanya yang didasarkan kecakapan, pengalaman dan kesungguhan serta waktu". Prestasi kerja merupakan gabungan dari tiga faktor penting yaitu kemampuan dan minat seorang pekerja, kemampuan menerima atas penjelasan delegasi tugas, serta peran di tingkat motivasi seorang pekerja. Seorang pegawai dalam melaksanakan pekerjaan dan tugas-tugasnya harus dengan rasa penuh tanggung jawab. Apabila pegawai dalam melaksanakan pekerjaan dan tugas-tugasnya dengan penuh tanggung jawab berarti dirinya telah melaksanakan disiplin kerja. Dengan adanya disiplin kerja, diharapkan seluruh pegawai dapat mematuhi segala peraturan-peraturan dalam organisasi dan dapat menjalin rasa kebersamaan antara seorang manajer dengan bawahannya. hal itu sependapat dengan Simamora (2004:88) (Uno, 2008) yang menyatakan bahwa terdapat dua tujuan utama dalam melaksanakan disiplin, "pertama adalah tindakan disiplin memastikan bahwa perilakuperilaku pegawai konsisten dengan aturan-aturan organisasi, kedua adalah menciptakan /mempertahankan rasa hormat dan saling percaya diantara atasan dan bawahannya". Dengan meningkatkan disiplin kerja, seorang pegawai diharapkan dapat meningkatkan kinerjanya dalam organisasi dan menjadikan kinerjanya lebih baik. Dengan disiplin kerja para pegawai yang tinggi, maka akan lebih mudah dalam mencapai tujuan organisasi. sehingga mengisyaratkan bahwa terdapat hubungan yang positif antara disiplin kerja dengan kinerja pegawai dalam sebuah organisasi.

Berdasarkan hasil analisis data dan beberapa pendapat para ahli mengenai keterkaitan antara Disiplin Kerja dengan Kinerja Pegawai di Dinas Pendidikan Kabupaten Mojokerto, maka dapat disimpulkan bahwa terdapat hubungan yang nyata antara Disiplin Kerja dengan Kinerja Pegawai. Sehingga dapat disimpulkan bahwa hasil penelitian ini mendukung teori yang telah ada.

Berdasarkan hasil analisis penelitian ini dapat disimpulkan bahwa motivasi kerja (X1) dan disiplin kerja (X2) berhubungan dengan kinerja pegawai (Y) di Dinas Pendidikan Kabupaten Mojokerto. Hipotesis ketiga terjawab dengan melihat nilai signifikan yang diperoleh adalah 0,000. Nilai signifikan ini lebih kecil dari pada nilai alpha 0,05 maka dapat disimpulkan bahwa motivasi kerja dan disiplin kerja berhubungan dengan kinerja pegawai sehingga hipotesis ketiga teruji kebenarannya.

Kinerja pegawai merupakan keberhasilan seorang pegawai dalam pekerjaannya. Hal itu sependapat dengan Sutrisno (2007:171) yang menyatakan bahwa "kinerja pegawai adalah prestasi yang diperoleh seseorang dalam melaksanakan tugas". Agar setiap pegawai dapat meningkatkan kinerjanya saat bekerja, maka dibutuhkan motivasi baik dari dalam dirinya sendiri maupun dari luar. Dengan diberikan motivasi diharapkan dapat memberikan dorongan pada pegawai untuk selalu dapat bekerja lebih produktif dan dapat mengembangkan potensi dalam dirinya. Pemberian motivasi juga akan meningkatkan semangat kerja saat pegawai merasa lelah dan stress akan pekerjaannya. Secara tidak langsung akan menggugah dirinya untuk lebih berusaha agar dapat menyelesaikan pekerjaan yang telah menjadi tanggung jawabnya. Menurut Hasibuan (2003:97) pemberian motivasi bertujuan agar: 1) mendorong gairah dan semangat kerja; 2) meningkatkan moral dan semangat kerja; 3) meningkatkan produktivitas kerja; 4) mempertahankan loyalitas dan kestabilan bawahan; 5) meningkatkan kedisiplinan dan menurunkan tingkat absensi; 6) mengefektifkan pengadaan tenaga kerja yang baik; 7) meningkatkan kreativitas dan patisipasi; 8) meningkatkan tingkat kesejahteraan; 9) mempertinggi rasa tanggung jawab terhadap tugas-tugas; dan 10) meningkatkan efisiensi penggunaan alat-alat bahan baku. Dengan motivasi kerja yang tinggi diharapkan dapat mencapai kinerja yang baik dan memudahkan dalam pencapaian suatu tujuan organisasi. Sehingga ada hubungan antara motivasi kerja dengan kinerja pegawai.

Kedisiplinan dalam bekerja harus ditegakkan dalam sebuah organisasi. Karena dengan disiplin kerja para pegawai, produktivitas kerja organisasi dapat meningkat. Seorang pegawai yang bekerja dengan disiplin, maka dia akan termotivasi untuk selalu melaksanakan tugas dan pekerjaannya sesuai dengan tuntutan organisasi. Tidak hanya itu, disiplin kerja juga dapat mendidik 
pegawai agar senantiasa mematuhi dan mentaati segala peraturan-peraturan yang berlaku dalam organisasi. Sehingga dengan disiplin kerja yang tinggi maka akan membantu memajukan organisasi kedepannya. Dengan penerapan disiplin kerja diharapkan produktivitas pegawai akan lebih tinggi sesuai dengan harapan organisasi. Tanpa adanya disiplin pegawai, sangatlah sulit bagi organisasi untuk dapat menciptakan kinerja yang optimal. Sehingga terdapat hubungan antara disiplin kerja dengan kinerja pegawai.

Berdasarkan hasil analisis data dan beberapa pendapat para ahli mengenai keterkaitan antara Motivasi Kerja dan Disiplin Kerja dengan Kinerja Pegawai di Dinas Pendidikan Kabupaten Mojokerto, maka dapat disimpulkan bahwa terdapat hubungan yang nyata antara Motivasi Kerja dan Disiplin Kerja dengan Kinerja Pegawai. Sehingga dapat disimpulkan bahwa hasil penelitian ini mendukung teori yang telah ada.

\section{KESIMPULAN}

Berdasarkan hasil pembahasan mengenai Hubungan Motivasi Kerja dan Disiplin Kerja dengan Kinerja Pegawai di Dinas Pendidikan Kabupaten Mojokerto, maka diperoleh kesimpulan sebagai berikut:

Berdasarkan hasil analisis data yang diperoleh dari tabel korelasi product moment (X1 dengan Y) dengan taraf signifikan 0,000. Nilai signifikan ini lebih kecil dari pada nilai alpha 0,05. Nilai koefisien korelasi antara motivasi kerja (X1) dengan Kinerja Pegawai (Y) sebesar 0,792, hal ini berada pada tingkat hubungan yang kuat. Sehingga dapat disimpulkan bahwa Terdapat hubungan motivasi kerja (X1) dengan kinerja pegawai (Y) di Dinas Pendidikan Kabupaten Mojokerto.

Berdasarkan hasil analisis data yang diperoleh dari tabel korelasi product moment (X2 dengan Y) dengan taraf signifikan 0,000. Nilai signifikan ini lebih kecil dari pada nilai alpha 0,05. Nilai koefisien korelasi antara disiplin kerja (X2) dengan Kinerja Pegawai (Y) sebesar 0,981, hal ini berada pada tingkat hubungan yang sangat kuat. Sehingga dapat disimpulkan bahwa Terdapat hubungan disiplin kerja (X1) dengan kinerja pegawai (Y) di Dinas Pendidikan Kabupaten Mojokerto.

Berdasarkan hasil analisis data yang diperoleh dari tabel korelasi ganda (X1 dan X2 dengan Y) dengan taraf signifikan 0,000. Nilai signifikan ini lebih kecil dari pada nilai alpha 0,05. Nilai koefisien korelasi antara motivasi kerja (X1) dan disiplin kerja (X2) dengan Kinerja Pegawai (Y) sebesar 0,981, hal ini berada pada tingkat hubungan yang sangat kuat. Sehingga dapat disimpulkan bahwa Terdapat hubungan motivasi kerja (X1) dan disiplin kerja (X2) dengan kinerja pegawai (Y) di Dinas Pendidikan Kabupaten Mojokerto

\section{REKOMENDASI}

Berdasarkan paparan data, hasil penelitian serta kesimpulan, adapun beberapa saran untuk pihak yang terkait, antara lain:

Bagi Kepala Dinas Pendidikan Kabupaten Mojokerto diharapkan agar lebih menegakkan disiplin kerja. Pengawasan dan pemberian sanksi dari pimpinan sangat dibutuhkan agar pegawai patuh terhadap jam kerja sehingga dapat menyelesaikan tugas dengan baik. Dengan kedisiplinan dalam bekerja, kinerja pegawai akan lebih meningkat. Sehingga organisasi akan berjalan dengan lancar dan tertib sesuai dengan tujuan organisasi.

Bagi pegawai Dinas Pendidikan Kabupaten Mojokerto, diharapkan selalu meningkatkan motivasi kerja disetiap pekerjaan. Hal itu diperlukan agar dapat menambah semangat kerja pada diri pegawai sehingga memudahkan untuk mencapai tujuan organisasi. 
Bagi pegawai Dinas Pendidikan Kabupaten Mojokerto, diharapkan selalu meningkatkan kinerja disetiap pekerjaan. Dengan kinerja yang optimal diharapkan dapat memberikan pelayanan yang prima kepada seluruh warga masyarakat Kabupaten Mojokerto

\section{REFERENSI}

Abdullah, M. (2014). Manajemen dan evaluasi kinerja karyawan. Aswaja Pressindo.

Aprilianto, A., \& Arif, M. (2019). Pendidikan Islam dan Tantangan Multikultural: Tinjauan Filosofis. Nazhruna: Jurnal Pendidikan Islam, 2(2), 279-289. https://doi.org/10.31538/nzh.v2i2.339

Arifudin, A., Sudirman, S., \& Andri, M. (2017). Evaluasi Sistem Manajemen Sumber Daya Manusia Pada Penempatan Kerja Petugas Di Upt Puskesmas Lembasada. PROMOTIF: Jurnal Kesehatan Masyarakat, 7(1), 1-14. https://doi.org/10.31934/promotif.v7i1.20

Badudu, Y., \& Zain, S. M. (1994). Kamus umum bahasa Indonesia (Cet. 1). Pustaka Sinar Harapan.

Barmawi, M. (2017). Peranan Lingkungan terhadap Semangat Belajar dalam Khazanah Kitab Kuning. Edukasia Islamika, 134-160. http://ejournal.iainpekalongan.ac.id/index.php/edukasiaislamika/article/view/773

E Mulyasa. (2011). Menjagi Guru Profesional Menciptakan Pembelajaran Kreatif dan Menyenangkan (11th ed.). Rosdakarya.

Ekosusilo, M., \& Soepardjo, S. (2014). Faktor Dominan Yang Memengaruhi Motivasi Kerja, Kinerja, Dan Kepuasan Kerja Guru SMA. Jurnal Ilmu Pendidikan, 20(2).

Gordon, W., Oliva, P. F., \& Taylor, R. (2019). Developing the curriculum: Improved outcomes through systems approaches (Ninth edition). Pearson.

Hamzah B, U. (2011). Profesi Kependidikan, Problema, Solusi dan Reformasi di Indonesia. Bumi Aksara.

Hasibuan, J. J. (1988). Proses belajar mengajar: Ketrampilan dasar pengajaran mikro. Remaja Rosdakarya, Bandung.

Kartiko, A., \& Azzukhrufi, jaya R. (2019). Pengaruh Budaya Organisasi Dan Kompensasi Terhadap Kinerja Pendidik Di Madrasah Aliyah Nahdlatul Ulama Mazro'atul Ulum Paciran. Nidhomul Haq : Jurnal Manajemen Pendidikan Islam, 4(2), 207-226. https://doi.org/10.31538/ndh.v4i2.351

Ma`arif, M. A., \& Rochmah, S. (2018). Target Hafalan sebagai Motivasi Belajar dalam Membentuk Karakter di Lingkungan Pesantren. Muróbbî: Jurnal Ilmu Pendidikan, 2(1), 105127. http://jurnal.iaibafa.ac.id/index.php/murobbi/article/view/127

Mangkunegara, A. A. A. P. (2000). Manajemen sumber daya manusia perusabaan. Remaja Rosdakarya.

Megawangi, R. (2005). Membangun SDM Indonesia Melalui Pendidikan Holistik Berbasis Karakter. Jakarta: Direktorat Pembinaan TK Dan SD [Taman Kanak-Kanak Dan Sekolah Dasar].

Siagian, S. P. (2002). Manajemen sumber daya manusia. Bumi aksara.

Sinambela, L. P. (2016). Manajemen Sumber Daya Manusia / Lijan Poltak Sinambela; editor, Suryani (ed. 1 cet. 1). Bumi Aksara.

Stoner, A. F., Freeman, R. E., \& Gilbert, D. R. (1996). Manajemen Edisi Bahasa Indonesia. PT. Prenhallindo. Jakarta.

Suprihatin, S. (2015). Upaya Guru Dalam Meningkatkan Motivasi Belajar Siswa. Promosi Jurnal Pendidikan Ekonomi), 3(1). https://doi.org/10.24127/ja.v3i1.144

Swasto, B. (2011). Manajemen sumber daya manusia. Malang: UB Press. 
Ubabuddin. (2019). Meningkatkan Kinerja Guru Melalui Supervisi Pembelajaran. Ed-Humanistics, $4(1)$.

Uno, H. B. (2008). Teori Motivasi \& Pengukurannya: Kajian \& Analisis Di Bidang Pendidikan.

Wahjono, S. I. (2010). Perilaku organisasi. Yogyakarta: Graha Ilmu.

Wahjono, S. I. (2015). Manajemen sumber daya manusia. Salemba Empat.

Wendt, D. C., \& Gone, J. P. (2016). Integrating Professional and Indigenous Therapies: An Urban American Indian Narrative Clinical Case Study $\psi$. The Counseling Psychologist, 44(5), 695-729. https://doi.org/10.1177/0011000016638741 